\title{
Unia Europejska wobec bezpieczeństwa żywnościowego
}

\begin{abstract}
Streszczenie: Celem głównym artykułu jest przedstawienie istotnej kwestii stanowiska Unii Europejskiej wobec bezpieczeństwa żywnościowego. W UE ochrona zdrowia ludzkiego, zdrowia zwierząt i roślin na każdym etapie procesu produkcji żywnościowej ma priorytetowe znaczenie. Problem ten jest ściśle związany z nadmierną niestabilnością cen surowców, w tym także artykułów żywnościowych, co wpływa zarówno na producentów, jak i na konsumentów i wywołuje poważne skutki dla bezpieczeństwa żywnościowego. Warto podkreślić, że w okresie charakteryzującym się nagłymi zmianami cen żywności, takim jak lata 2007-2008, nastąpiło pogorszenie sytuacji żywnościowej w wielu ubogich krajach rozwijających się. Przewidywano, że wzrost cen żywności z 2010 r. może doprowadzić do dalszego rozszerzenia się zjawiska niedożywienia, zapotrzebowania na pomoc humanitarną oraz dalszej intensyfikacji napięć i niepokojów społecznych wśród słabszych konsumentów na świecie. Ważną rolę w zmianie tej sytuacji może odegrać Światowa Organizacja Handlu (WTO) oraz Unia Europejska. Kwestie bezpieczeństwa żywnościowego także dla Unii Europejskiej są równocześnie niezwykle ważne i aktualne zarówno z punktu widzenia teoretycznego, jak i praktycznego.
\end{abstract}

Slowa kluczowe: Unia Europejska, bezpieczeństwo żywnościowe, ochrona konsumentów, bezpieczna żywność, poziom cen, niestabilność cen

\section{Wprowadzenie ${ }^{1}$}

We współczesnym rozwoju gospodarki światowej i w Unii Europejskiej kwestie bezpieczeństwa żywnościowego są niezwykle ważne i aktualne. Celem unijnej polityki bezpieczeństwa żywności jest zapewnienie obywatelom Unii Europejskiej bezpiecznej żywności o wysokiej wartości odżywczej i jednocześnie zagwarantowanie, aby przemysł spożywczy - największy sektor wytwórczy i zatrudnienia w Europie - mógł działać w możliwie najlepszych warunkach. Polityka UE chroni zdrowie w całym łańcuchu rolno-spożywczym obejmującym wszystkie etapy produkcji żywności od hodowli po konsumpcję poprzez zapobieganie skażeniu żywności, promowanie higieny żywności i rozpowszechnianie informacji na temat żywności, zdrowia roślin oraz zdrowia i dobrostanu zwierząt. Bezpieczeństwo żywnościowe UE uzależnione jest także od poziomu cen. Warto przy tym podkreślić, że wyższe ceny światowe mogą stymulować produkcję i wzrost handlu międzynarodowego, lecz mechanizmy transmisji cen są często niedoskonałe. Rynki towarowe wielu państw często funkcjonują w oderwaniu od rynków światowych, lub też sygnały dotyczące cen światowych przekazywane są, jeśli w ogóle są przekazywane, na rynki wewnętrzne ze znacznym opóźnieniem, co powoduje, że odpowiedź podaży krajowej jest często opóźniona. Trzeba zaznaczyć, że Organizacja ds. Wyżywienia i Rolnictwa (FAO), Organizacja Współpracy Gospodarczej i Rozwoju

${ }^{1}$ Artykuł wykonany w ramach Grantu OPUS, Narodowego Centrum Nauki - NCN, nr UMO 2013/11/B/HS5/03572. 
(OECD), Komisja Europejska (KE) Unii Europejskiej (UE) i inne instytucjonalne podmioty współczesnej gospodarki światowej przeprowadziły szereg analiz poświęconych zmianom w podaży i popycie, nasilonym przez krótkoterminowe czynniki gospodarcze i polityczne (w tym ograniczenia w wywozie takie jak cła i środki pozataryfowe), które wyjaśniają niektóre przyczyny zaobserwowanej wyjątkowej niestabilności cen żywności, w tym czynniki charakterystyczne dla rynków finansowych, które mogły przyczynić się do jeszcze większej zmienności cen. W pracy zastosowano ilościowe i jakościowe metody badawcze. Celem głównym pracy jest przedstawienie stanowiska Unii Europejskiej wobec istotnej kwestii bezpieczeństwa żywnościowego.

\section{Polityka bezpieczeństwa żywnościowego Unii Europejskiej}

Bezpieczeństwo żywnościowe uznane zostało za jedną z głównych sił napędowych reformy Wspólnej Polityki Rolnej (WPR do 2020 r., COM, 2010). Warto podkreślić, że silny sektor rolny jest niezbędny dla istnienia wysoko konkurencyjnego przemysłu spożywczego, będącego ważną częścią gospodarki i handlu UE oraz w istotny sposób oddziałującego na rynki międzynarodowe (Alt, Frieden, Gilligan, Rogowski, 1996; Alt, Gilligan, 1994; Goldstein, 1989; Goldstein, 2001). Z tego względu, w kontekście Rundy Doha, UE zgodziła się na ważny pakiet rolny, uzależniony od osiagnięcia ambitnego, zrównoważonego i kompleksowego porozumienia ogólnego.

Celem polityki Unii Europejskiej w zakresie bezpieczeństwa żywności jest ochrona konsumentów oraz jednoczesne zagwarantowanie niezakłóconego działania jednolitego rynku. Od 2003 r. polityka ta koncentruje się na koncepcji identyfikacji zarówno środków produkcji (np. paszy dla zwierząt), jak i wyników (np. produkcji podstawowej, przetwarzania, składowania, transportowania i sprzedaży detalicznej). UE ustanowiła normy kontroli w zakresie higieny żywności i produktów żywnościowych, zdrowia i dobrostanu zwierząt, zdrowia roślin oraz zapobiegania zagrożeniu zanieczyszczenia substancjami zewnętrznymi, takimi jak pestycydy. Na każdym etapie przeprowadzane są rygorystyczne kontrole, a przywóz żywności (np. mięsa) spoza UE musi spełniać te same normy i przechodzić takie same kontrole jak żywność produkowana na terenie UE.

Unijna polityka bezpieczeństwa żywności ma trzy główne cele:

- zapewnienie, aby żywność i pasza dla zwierząt były bezpieczne i miały wysoką wartość odżywczą,

- zapewnienie wysokiego poziomu ochrony zdrowia i dobrostanu zwierząt oraz ochrony roślin,

- zapewnienie dokładnych i przejrzystych informacji o pochodzeniu, składzie i etykietowaniu oraz wykorzystaniu żywności.

Podkreślić należy, że zapewnienie zdrowej żywności w Unii Europejskiej jest zadaniem transgranicznym, ponieważ duża część spożywanych produktów pochodzi z różnych państw. Rynek Unii Europejskiej jest przy tym rynkiem jednolitym, co oznacza, że towary można sprzedawać swobodnie na terenie całej UE. Do takich towarów należy również żywność. Dzięki temu konsumenci mają znacznie większy wybór, a ceny są niższe z uwagi na większą konkurencję, co nie miałoby miejsca, gdyby żywność można było sprzedawać wyłącznie na terenie jednego kraju. Oznacza to jednak również, że 
trzeba ustanawiać ogólnounijne przepisy obejmujące najistotniejsze zasady dotyczące jakości i bezpieczeństwa. Warto także zaznaczyć, że gdyby każdy produkt musiał być kontrolowany w każdym kraju według różnych przepisów, nie istniałby wolny handel. Stosowanie różnych regulacji prawnych umożliwiłoby też producentom w niektórych krajach uzyskanie nieuczciwej przewagi konkurencyjnej.

Ponadto polityka rolna leży w gestii UE, co sprawia, że Unia może wpływać na jakość i bezpieczeństwo żywności, ustanawiając przepisy i przyznając wsparcie gospodarcze rolnikom. Dzięki tym unijnym przepisom obywatele UE mają zagwarantowane jedne z najsurowszych norm bezpieczeństwa żywności na świecie. W całym łańcuchu rolno-spożywczym przeprowadza się obowiązkowe kontrole w celu zapewnienia zdrowia roślin i zwierząt oraz zagwarantowania, by żywność i pasza dla zwierząt były bezpieczne, wysokiej jakości, by były odpowiednio etykietowane i spełniały surowe normy UE. W warunkach rynku globalnego spełnianie tych norm wiąże się z wieloma wyzwaniami. Należą do nich:

- zapobieganie wprowadzeniu chorób zwierząt i roślin do UE i ich rozpowszechnianiu się na terenie Unii,

- zapobieganie przenoszeniu się chorób ze zwierząt na ludzi. Obecnie istnieje ponad 200 chorób, które mogą przenieść się ze zwierząt na ludzi za pośrednictwem łańcucha żywnościowego, na przykład salmonella,

- zapewnienie utrzymania wspólnych przepisów w całej UE w celu ochrony konsumentów i zapobieganiu nieuczciwej konkurencji,

- ochrona dobrostanu zwierząt,

- zagwarantowanie, że konsumenci mają dostęp do jasnych, jednoznacznych informacji o składzie i pochodzeniu żywności,

- przyczynianie się do zachowania bezpieczeństwa żywnościowego na świecie i zapewnianie wystarczającego dostępu do bezpiecznej żywności wysokiej jakości. Szacuje się, że do 2030 r. trzeba będzie wykarmić 8 mld osób i że wzrośnie zapotrzebowanie na dietę bogatą w mięso. Światowa produkcja żywności musi zatem wzrosnąć o co najmniej $40 \%$, aby sprostać tym potrzebom, a $80 \%$ tego wzrostu będzie musiała zapewnić zwiększona produkcja roślinna (Zrozumieć politykę Unii Europejskiej..., 2014).

Podstawowe zasady polityki bezpieczeństwa żywności UE określa ogólne prawo żywnościowe Unii Europejskiej przyjęte w 2002 r. Jego celem jest ułatwienie wolnego handlu żywnością na terenie wszystkich krajów UE przez zapewnienie tego samego poziomu ochrony konsumentów we wszystkich państwach członkowskich. Prawo żywnościowe UE obejmuje szereg zagadnień dotyczących żywności ogółem, w szczególności jej bezpieczeństwa, w tym informacji na temat żywności oraz kwestii dotyczących dobrostanu zwierząt. Odnosi się ono do wszystkich etapów łańcucha żywnościowego, od paszy dla zwierząt i produkcji żywności po jej przetwarzanie, składowanie, transport, przywóz i wywóz, a także sprzedaż detaliczną.

Należy zaznaczyć, że dzięki zintegrowanemu podejściu można prześledzić drogę każdej żywności i paszy wyprodukowanej i sprzedanej w UE ,od pola do stołu”, a konsumenci otrzymują dokładne informacje o składzie spożywanych przez siebie produktów. W prawie żywnościowym UE ustanowiono również zasady analizy ryzyka. Określają one jak, kiedy i przez kogo przeprowadzana powinna być ocena naukowa i technicz- 
na mająca na celu zapewnienie odpowiedniej ochrony ludzi, zwierząt i środowiska. To wspólne podejście zapewnia stosowanie minimalnych norm w całej Unii. Dzięki niemu kraje UE mogą zapobiegać chorobom i je kontrolować, a także zmniejszać ryzyko dla bezpieczeństwa żywności i paszy w skoordynowany, skuteczny i opłacalny sposób (Zrozumieć politykę Unii Europejskiej..., 2014).

Warto podkreślić, że mimo nadal istniejącej niepewności, w oparciu o obraz towarów rolnych nakreślony przez kilka instytucji, w tym przez Komisję Europejską w jej ostatnich średniookresowych perspektywach, można wysnuć trzy jasne wnioski w odniesieniu do towarów rolnych:

- oczekuje się, że ceny towarów rolnych pozostaną na poziomie wyższym niż średnie ceny historyczne, co będzie stanowić odwrócenie dhugoterminowej tendencji spadkowej, przynajmniej w dającej się przewidzieć przyszłości;

- niestabilność cen także prawdopodobnie pozostanie duża, chociaż utrzymuje się niepewność co do jej przyczyn i czasu trwania;

- poziom cen nakładów wykorzystywanych w rolnictwie także prawdopodobnie pozostanie na poziomie wyższym niż obserwowany w przeszłości (Stawianie czoła wyzwaniom..., COM, 2011).

Połączenie powyższych czynników wskazuje na to, że wyższe ceny towarów rolnych niekoniecznie muszą przełożyć się na wyższe dochody rolników, zwłaszcza jeśli z powodu wyższych kosztów zmaleją ich marże. Ponadto oczywiste jest wystapienie potencjalnych problemów związanych z inflacją cen żywności, które dotkną kraje będące importerami żywności netto oraz, w sensie bardziej ogólnym, konsumentów znajdujących się w trudnej sytuacji. Pewien stopień zmienności stanowi wprawdzie nieodłączny element rynków rolnych, jednak nadmierna niestabilność cen nie przynosi korzyści ani producentom ani konsumentom (Stawianie czoła wyzwaniom..., 2011).

Warto podkreślić, że Komisja Europejska ustanowiła forum wysokiego szczebla w celu poprawy funkcjonowania łańcucha dostaw żywności i bezpieczeństwa żywnościowego. Chociaż przedmiotem prowadzonych w jego ramach prac nie jest niestabilność cen, zajmuje się ono problemem transmisji zmian cen w ramach łańcucha dostaw, badając stosunki między przedsiębiorstwami, konkurencyjność przemysłu spożywczego, logistykę łańcucha rolno-spożywczego oraz narzędzia do monitorowania cen żywności.

\section{Unia Europejska jako kreator bezpieczeństwa żywnościowego w skali globalnej}

Przystępując do rozważań tego interesującego zagadnienia warto podkreślić, że nagłe zmiany cen żywności uwypukliły problem niedoinwestowania rolnictwa, z którym przede wszystkim kraje rozwijające się, zwłaszcza w Afryce, walczą od kilku ostatnich dziesięcioleci². W deklaracji dotyczącej polityki rozwojowej UE, skierowanej do tych państw, uznano potrzebę odwrócenia tego trendu. Jak wskazano w Zielonej Księdze w sprawie polityki rozwojowej UE (COM 629 2010), może tu odegrać istotną rolę w obniżeniu wpływu niestabilności cen na ludność znajdującą się w najtrudniejszej sytuacji. Komisja Europejska przyjęła już ramy polityczne dotyczące bezpieczeństwa żywnościo-

${ }^{2}$ Mniej niż dziesięć państw afrykańskich wypełnia ustanowiony w 2003 r. w Maputo cel, zgodnie z którym dziesięć procent dochodów z inwestycji publicznych miało być przeznaczanych na rolnictwo. 
wego (COM 127, 2010), wskazując w nich, że UE i państwa członkowskie powinny przyczynić się do poprawy funkcjonowania rynku żywności na poziomie regionalnym i globalnym, zapewniając także większą przejrzystość rynkową (Maxwell, Engel, 2003) co podkreśla istotną rolę Unii Europejskiej jako kreatora bezpieczeństwa żywnościowego także w skali globalnej.

Działania UE w obszarze bezpieczeństwa żywnościowego pociąają za sobą wsparcie dla krajów rozwijających się w celu wzmocnienia organizacji rolników, zwiększenia przejrzystości cen żywności, trwałego zwiększenia wydajności produkcji rolnej, a także opracowania i stosowania ram regulacyjnych. Należy zaznaczyć, że rozwój produkcji rolnej w krajach rozwijających się przyczyni się do zwiększenia odporności na wstrząsy na światowym rynku żywności i zdolności adaptacyjnej państw trzeciego świata do tych wstrząsów. Warto także podkreślić, że szczególnie biorąc pod uwagę, jednostronne działania podejmowane przez niektóre rządy, ich wysoka aktywność w tym zakresie może także stanowić czynnik, mogący wpływać na rynki fizyczne i prowadzić do niestabilności cen. Istnieje zatem potrzeba bardziej efektywnego zarządzania i rozpoczęcia dialogu międzynarodowego w tym zakresie (Lister, 2003; Rifkin, 2004; Desai, Vreeland, 2011; Fukuda-Parr, 2011), szczególnie uwzględniając kwestie bezpieczeństwa żywnościowego.

Warto podkreślić, że efektywniejsze rządy i większa przejrzystość, podobnie jak dobry klimat dla wymiany handlowej $\mathrm{i}$ inwestycji w sektorze surowców w tym artykułów rolnych są niezbędne po to, aby w krajach bogatych w zasoby osiagnąć zrównoważony rozwój sprzyjający włączeniu społecznemu. Poprzez swoją politykę rozwoju i partnerstwo z krajami rozwijającymi się UE może odegrać kluczową rolę w tworzeniu sytuacji przynoszących obopólne korzyści, w których zarówno kraje rozwinięte, jak i rozwijające się będą korzystać ze stabilnych dostaw surowców w tym żywności, a także w wykorzystaniu krajowych zasobów finansowych przeznaczonych na zrównoważony rozwój w celu wsparcia strategii dotyczących rozwoju sprzyjającego włączeniu społecznemu oraz ograniczaniu ubóstwa.

Głównym motywem powyższych działań UE jest zapewnienie, by kwestie żywienia były częścią polityki rozwoju, polityki edukacyjnej i polityki zdrowotnej. Unia Europejska współpracuje z krajami rozwijającymi się na rzecz stworzenia systemów zarządzania żywnością, które mogłyby poprawić bezpieczeństwo żywnościowe dla ludzi najuboższych i najbardziej podatnych na zagrożenia. Do działań UE w dziedzinie rozwoju i pomocy humanitarnej należy: udzielanie porad przez ekspertów weterynarii, programy szkoleniowe i finansowanie programów kontroli i zwalczania chorób. Komisja prowadzi również inicjatywę szkoleniową pod nazwą „Lepsze szkolenia na rzecz bezpieczniejszej żywności”, w ramach której przewidziano działania w krajach nienależących do UE. Wprowadza się także projekt BTSF World o wartości $8 \mathrm{mln}$ euro mający na celu pomoc krajom rozwijającym się w zrozumieniu środków sanitarnych i fitosanitarnych, które pozwolą im na lepsze wykorzystanie handlu regionalnego i światowego.

Komisja Europejska rozważy te kwestie także w kontekście procesu konsultacji związanego z Zieloną Księgą w sprawie przyszłości polityki rozwojowej UE i wsparcia budżetowego, a także konsultacji publicznych dotyczących sprawozdawczości z podziałem na poszczególne kraje (http://ec.europa.eu/internal_market/consultations/2010/ financial-reporting_en.htm). UE będzie zachęcać rządy państw partnerskich do opracowania kompleksowych programów reform, które będą wyraźnie określać cele, takie jak 
usprawnienie systemów opodatkowania czy poprawa przejrzystości dochodów i umów, lub też większe możliwości wykorzystywania dochodów na wsparcie celów w zakresie rozwoju. Należy podkreślić, że większa przejrzystość pomoże społeczeństwu jako całości, a także krajowym organom nadzorczym rozliczać rządy i przedsiębiorstwa z płaconych podatków i uzyskiwanych dochodów, a zatem zmniejszy liczbę oszustw i przypadków korupcji oraz zapewni bardziej przewidywalne warunki dla wymiany handlowej i inwestycji.

Warto zaznaczyć, że kraje rozwijające się bogate w zasoby także rolne często cierpią na brak infrastruktury transportowej, energetycznej i środowiskowej, co ogranicza ich zdolność do wykorzystania bogactwa surowcowego w tym żywności na rzecz własnych społeczeństw. Biorąc to pod uwagę uznano, że Komisja Europejska, Europejski Bank Inwestycyjny (EBI) i inne europejskie instytucje finansujące rozwój, we wspólpracy z afrykańskimi władzami krajowymi i regionalnymi, będą kontynuować ocenę sposobów promowania najlepszej infrastruktury oraz kwestii związanych z rządami, co może przyczynić się do zrównoważonego wykorzystania zasobów tych krajów i ułatwić dostawy surowców w tym żywności, stosując dialog w ramach odpowiednich sektorów do sterowania tym procesem. Komisja Europejska dokona przede wszystkim oceny (a) możliwości zwiększenia wysokości pożyczek (z których część może mieć charakter dotacji), w szczególności w sektorach przetwórczych oraz (b) zbada możliwość promowania instrumentów finansowych, które obniżają ryzyko ponoszone przez podmioty gospodarcze poprzez gwarancje finansowane przez UE, w tym także przez Europejski Fundusz Rozwoju. Istniejący fundusz powierniczy UE na rzecz infrastruktury w Afryce ${ }^{3}$ mógłby pomóc krajom afrykańskim w realizacji tego zadania.

Nie należy przy tym zapominać o tym, że we współczesnym wielobiegunowym świecie, przy braku porozumienia końcowego Rundy Doha, coraz większego znaczenia nabierają porozumienia i więzi regionalne oraz porozumienia bilateralne (Puślecki, 2008; Desai, Vreeland, 2011). Ponadto, co jest także charakterystyczne, szczególnie dla kwestii teoretycznych, osłabieniu ulegają uzasadnienia o względach praktycznych na rzecz wzmacniania się rozwiązań normatywnych (Fukuda-Parr, 2011). Działania normatywne uwidaczniają się przy tym przede wszystkim w krajach trzeciego świata. Polegają one na przenoszeniu reguł o charakterze globalnym, głównie z państw wysoko rozwiniętych, na poziom działań regionalnych państw rozwijających się co nie zawsze przynosi oczekiwane efekty.

\section{Kierunki realizacji inicjatyw Unii Europejskiej na rzecz bezpieczeństwa żywnościowego}

Pomimo istotnych postępów poczynionych przy realizacji inicjatywy na rzecz surowców w tym żywności, niezbędne są w Unii Europejskiej dalsze usprawnienia w tej dziedzinie. Kwestią zasadniczą jest zintegrowane podejście, które przyczynia się do zapewnienia rzetelnych i stabilnych dostaw surowców w tym żywności do UE co jest szczególnie istotne ze względów bezpieczeństwa żywnościowego.

${ }^{3}$ Celem funduszu powierniczego jest wspieranie projektów na rzecz infrastruktury transgranicznej i regionalnej w Afryce Subsaharyjskiej. 
Warto podkreślić, że prowadzone na unijnych granicach kontrole roślin, zwierząt, żywności i pasz importowanych do UE są niezbędne, aby chronić zdrowie zwierząt, roślin i zdrowie publiczne oraz zapewnić, że wszystkie przywożone towary spełniają unijne normy i mogą być bezpiecznie wprowadzone do obrotu na unijnym rynku. Kontrole graniczne dostosowane są do różnych produktów i towarów i uwzględniają ryzyko dla zdrowia, jakie mogą stanowić. Przykładowo przesyłki żywych zwierząt lub roślin mogą być wprowadzane do UE tylko w wyznaczonych punktach wjazdowych i po pomyślnym przejściu określonych kontroli. Ścisłe zasady rozprowadzania i kontrole dotyczą również określonej żywności, paszy oraz produktów pochodzenia zwierzęcego (takich jak wełna, skóry, zarodki i produkty uboczne pochodzenia zwierzęcego). Większość z tych towarów musi posiadać szczególne gwarancje odnoszące się do ich statusu zdrowotnego (np. świadectwo weterynaryjne lub fitosanitarne).

Zapewnienie dostaw surowców, w tym żywności, należy zasadniczo do zadań przedsiębiorstw, a rolą władz publicznych jest zapewnienie odpowiednich ram umożliwiających tym przedsiębiorstwom wykonanie tego zadania. Na przedsiębiorcach spoczywa także główna odpowiedzialność za zapewnienie, by żywność, którą wprowadzają do obrotu, była bezpieczna. Ścisłe i regularne kontrole urzędowe przeprowadzane przez organy państw członkowskich zapewniają spełnienie i utrzymanie wysokich norm UE dotyczących żywności i paszy. Urzędowe kontrole mają na celu egzekwowanie stosowania przepisów. Kontrole przeprowadzane są regularnie przez niezależne, bezstronne i dobrze wyszkolone organy i obejmują wszystkie podmioty wchodzące w skład łańcucha rolno-spożywczego. Podmioty te muszą stosować najnowsze technologie i metody oraz - w razie potrzeby przeprowadzenia badań lub analiz w celu sprawdzenia zgodności z przepisami - korzystają z rozbudowanej sieci urzędowych laboratoriów. Inspektorzy z Biura ds. Żywności i Weterynarii Komisji Europejskiej kontrolują organy krajowe i zapewniają stosowanie unijnych przepisów na terytorium całej UE. Komisja jest gotowa zbadać, we współpracy z państwami członkowskimi wartość dodaną i wykonalność ewentualnego programu magazynowania surowców w tym żywności. Na poziomie UE program magazynowania surowców w tym żywności ma na celu ochronę bezpieczeństwa publicznego w państwach członkowskich UE (Dyrektywa Rady, 2009).

Należy zaznaczyć, że Komisja Europejska zamierza wzmocnić strategię handlu surowcami, w tym żywnością, zgodnie z celami rozwoju i dobrych rządów. Komisja proponuje, aby we współpracy z państwami członkowskimi i z pełnym poszanowaniem zasady pomocniczości, przeprowadzić analizę możliwości ustanowienia mechanizmu monitorowania działań podejmowanych przez państwa członkowskie. Istotne jest również poszerzenie bazy wiedzy niezbędnej do opracowania skutecznej strategii na rzecz surowców w tym żywności. W perspektywie krótkoterminowej Komisja proponuje, aby we współpracy z państwami członkowskimi przeprowadzić ocenę zakresu zwiększonej synergii, dzięki czemu możliwe byłoby uzyskanie korzyści skali, niższych kosztów i większych możliwości podejmowania wspólnych projektów.

W perspektywie średniookresowej synergia powinna w sposób skoordynowany przyczynić się do poszerzenia europejskiej bazy wiedzy na temat surowców w tym żywności. W przypadku niektórych surowców, rosnący popyt sprawia, że inne surowce stają się bardziej konkurencyjne. Rosnącemu popytowi nie zawsze odpowiada jednak stosowne zwiększenie podaży, co skutkuje wzrostem cen. 
Podkreślić należy, że bezpieczeństwo żywności również w przyszłości pozostanie w centrum zainteresowania organów europejskich. Oprócz kontroli jakości Komisja Europejska przedstawiła wiele konkretnych propozycji umocnienia, modernizacji i uproszczenia obecnych unijnych przepisów w zakresie zdrowia zwierząt i roślin stosowanych jako materiał rozmnożeniowy. Propozycje te, przedstawione przez Komisję Europejską w maju 2013 r., dotyczą również przepisów, jakim podlegają urzędowe kontrole, aby zapewnić ich skuteczne egzekwowanie. Ich celem jest poprawa możliwości zapobiegania chorobom zwierząt i roślin i zmniejszenie ich liczby, poprawa wskaźnika reakcji UE na zagrożenia zdrowia oraz stosowanie nowych technologii i zapewnienie lepszego wykorzystania przepisów.

Istotnym problemem jest także zmniejszenie marnotrawstwa żywności. Należy zaznaczyć, że każdego roku w Europie marnuje się ponad $100 \mathrm{mln}$ ton żywności (Zrozumieć politykę Unii Europejskiej..., 2014). Szacunki te nie obejmują odpadów rolno-spożywczych ani odrzutów ryb. Żywność marnuje się na każdym etapie łańcucha żywnościowego: na etapie produkcji podstawowej, produkcji żywności, sprzedaży detalicznej i hurtowej, usług żywnościowych (cateringu) i na poziomie konsumenta. Marnotrawstwo żywności ma także negatywny wpływ na środowisko naturalne, gospodarkę i społeczeństwo. Warto zauważyć, że Unia Europejska zamierza do 2020 r. zmniejszyć o połowę ilość odpadów żywnościowych nadających się do spożycia w ramach strategii na rzecz efektywnej gospodarki, zasobami. Jedna z inicjatyw krótkoterminowych ma na celu zwiększenie świadomości konsumentów w zakresie marnotrawienia żywności.

W ramach inicjatywy przewodniej dotyczącej efektywnego gospodarowania zasobami będącej elementem strategii „Europa 2020” Komisja przedstawi mapę drogową dla Europy efektywnie korzystającej z zasobów. Będzie ona zawierać wizję zmian strukturalnych i technologicznych, jakie będą musiały zajść do roku 2050, aby można było przejść na gospodarkę, efektywnie korzystającą z zasobów i odporną na zmiany klimatu oraz przedstawi wskazówki dotyczące sposobu tego przejścia z wykorzystaniem polityk, które przyniosą największe korzyści dla wzrostu gospodarczego UE, tworzenia nowych miejsc pracy i bezpieczeństwa żywnościowego.

\section{Zakończenie}

Żywność i surowce rolne stanowią istotny element wyjściowy dla konkurencyjności przemysłu rolno-spożywczego oraz dla rozwoju nowych technologii w tej dziedzinie. Warto podkreślić, że kluczem do przyszłego potencjału Unii Europejskiej w tym obszarze są innowacje, które mogą odegrać ważną rolę w sprostaniu stawianym wyzwaniom. Potrzeba innowacji dotyczy całego łańcucha dostaw żywności i surowców rolnych w tym zrównoważonego przetwarzania, ekoprojektu, możliwości zastapienia, efektywnego gospodarowania zasobami i zagospodarowania przestrzennego. Należy zaznaczyć, że uruchomienie partnerstwa innowacji w dziedzinie surowców w tym żywności jest bardzo ważne w ramach projektu przewodniego strategii Europa 2020 noszącego nazwę Unia Innowacyjna i jej instrumentu finansowego pod nazwą Horyzont 2020.

Coraz wyraźniej podkreśla się, że społeczność międzynarodowa musi przyjać długofalowe skoordynowane podejście na rzecz światowego bezpieczeństwa żywnościowego, 
obejmujące zwiększenie nakładów na badania i inwestycje w sektorze rolnym w krajach rozwijających się, w szczególności przez wyznaczenie priorytetów polityki rozwoju na rzecz zwiększenia odporności na wstrząsy na rynku żywności oraz zdolności dostosowywania się do nich. Należy zaznaczyć także ważność kwestii poprawy zdolności rynków rolnych w zakresie prawidłowego funkcjonowania i znaczenie handlu międzynarodowego w osiąganiu równowagi pomiędzy poszczególnymi podmiotami na rynkach rolnych oraz poprawę dostępu rolników do surowców i energii. Istotne są również konkretne działania na rzecz zapewnienia bezpieczeństwa żywnościowego i rozwiązywania problemów niestabilności rynku oraz zwiększenia wydolności rynków instrumentów pochodnych na surowce rolne, w oparciu o trwałą odpowiedzialność ogólną.

\section{Bibliografia}

Agricultural Trade and its Importance (2006), European Commission, Brussels.

Alt J. E., Frieden J., Gilligan M. J., Rodrik D., Rogowski R. (1996); The Political Economy of International Trade: Enduring Puzzles and an Agenda for Inquiry, "Comparative Political Studies", no. 29.

Alt J. E., Gilligan M. J. (1994), The Political Economy of Trading States, "Journal of Political Philosophy", no. 2.

Ceny żywności w Europie oraz stanowiący jego uzupełnienie dokument roboczy służb Komisji SEC, 2008, COM, 821.

Desai R. M., Vreeland J. R. (2011), Global Governance in a Multipolar World: The Case for Regional Monetary Funds, "International Studies Review" 13, March, s. 109-121

Directive 2006/123/EC of the European Parliament and of the Council of 12 December 2006 on services in the internal market, OJ L 376 of 27.12.2006, Preambuła, pkt 5.

Directive 2006/123/EC of the European Parliament and of the Council of 12 December 2006 on services in the internal market, OJ L 376 of 27.12.2006.

Documents 2010/11, seoulsummit_declaration.pdf.

EU Trade in Agriculture (2006), European Commission, Brussels.

Fukuda-Parr S. (2011), Theory and Policy in International Development: Human Development and Capability Approach and the Millenium Development Goals, "International Studies Review", 13, March, s. 122-132.

Goldstein J. (1989), The Impact of Ideas on Trade Policy: The Origins of U.S. Agricultural and Manufacturing Policie, "International Organization", no. 43.

Goldstein J. S. (2001); International Relations, Fourth edition, Longman, New York.

Komunikat Komisji do Parlamentu Europejskiego, Rady, Europejskiego Komitetu Ekonomiczno-Społecznego i Komitetu Regionów Budżet z perspektywy „Europy 2020”, COM(2011)500 wersja ostateczna z 29.6.2011.

Komunikat Komisji do Parlamentu Europejskiego, Rady, Europejskiego Komitetu Ekonomiczno-Społecznego i Komitetu Regionów WPR do 2020 r.: sprostać wyzwaniom przyszłości zwiazanym z żywnościa, zasobami naturalnymi oraz aspektami terytorialnymi, COM (2010)672 wersja ostateczna z 18.11.2010.

Konkluzje Prezydencji Rady Europejskiej Unii Europejskiej z 18.3.2011.

Lister M. (2003), EU Development Policymaking in a Globalizing World, EADI conference, EU in the World, Brussels, May 19.

.Maxwell S., Engel P. (2003), European Development Cooperation to 2010, Overseas Development Institute, Working Paper nr 219. 
Polityka rozwojowa UE na rzecz wzrostu sprzyjajqcego włqczeniu społecznemu i zrównoważonego rozwoju. Zwiększenie skuteczności polityki rozwojowej UE, COM 629, 2010.

Poprawa funkcjonowania łańcucha dostaw żywności w Europie, COM 591, 2009.

Puślecki Z. W. (2008), Mercantilist Tendencies in Contemporary Foreign Trade Policy, "Journal of Global Change and Governance", Division of Global Affairs (DGA), Rutgers University, New Jersey, USA, vol. I, no. 4, Autumn.

Rezolucja Parlamentu Europejskiego z 23 czerwca 2011 r., 2011/2015(INI).

Rifkin J. (2004), The European Dream, Penguin, New York.

Rozporządzenie Parlamentu Europejskiego i Rady (UE) nr 1095/2010 z dnia 24 listopada 2010 r. w sprawie ustanowienia Europejskiego Urzędu Nadzoru (Europejskiego Urzędu Nadzoru Giełd i Papierów Wartościowych), zmiany decyzji nr 716/2009/WE i uchylenia decyzji Komisji 2009/77/WE, Dz. U. L 331 z 15.12.2010, s. 84.

Stawianie czoła wyzwaniom zwiqzanym z rynkami towarowymi i surowcami, 25 wersja ostateczna, Komunikat Komisji do Parlamentu Europejskiego, Rady, Europejskiego Komitetu EkonomicznoSpołecznego i Komitetu Regionów, Komisja Europejska, Bruksela, dnia 2.2.2011 COM 2011.

Unijne zasady ramowe dotyczqce wsparcia krajów rozwijajacych się $w$ zakresie wyzwań zwiazanych z bezpieczeństwem żywnościowym, COM 127, 2010.

Zrozumieć politykę Unii Europejskiej - Bezpieczeństwo żywności (2014) Komisja Europejska Dyrekcja Generalna ds. Komunikacji Społecznej Dział Informacji dla Obywateli 1049 Bruksela BELGIA, tekst zaktualizowano w czerwcu 2014 r., Urząd Publikacji Unii Europejskiej, Luksemburg.

\title{
European Union in the face of food security
}

\begin{abstract}
Summary
The main objective of this paper is to present the attitude of the European Union to the issue of food security. Price volatility in the global market has a significant impact on the economic security of the participants. This particulary applies to commodity price volatility. Excessive volatility in commodity price effects both producers and consumers has a serious implication for food security. In the context of globalisation in a period characterized by sudden changes in food prices, such as for 2007-2008, the food situation in many poor developing countries worsend. It was expected that the increase in food prices in 2010 may lead to the further spread of the phenomenon of malnutrition and further intensification of tensions and unrest among the weaker consumers in the world. An important role in changing this situation can be played by the World Trade Organisation (WTO) and European Union. Food security issues also for the European Union are very important and actual both from theoretical and practical point of view.
\end{abstract}

Key words: the European Union, food security, consumers protection, safe food, price volatility. 